\title{
Influence of environmental factors on the intensity of tomato plant transpiration
}

\author{
Zhuravlov $0 .^{1}$, Shatkovskyi A. ${ }^{2}$ \\ Institute of Water Problems and Land Reclamation of NAAS \\ 37, Vasylkivska Str., Kyiv, 03022, Ukraine \\ e-mail: ${ }^{1}$ zhuravlov_olexandr@ukr.net, ${ }^{2}$ andriy-1804@ukr.net; \\ ORCID: ${ }^{1}$ 0000-0001-7035-219X, ${ }^{2}$ 0000-0002-4366-0397
}

Goal. To study the influence of environmental factors on the transpiration intensity of tomato plants and to build a model of transpiration intensity based on the multiple linear regression (MLR). Methods. General scientific: vegetation, laboratory, measurement-calculation, and mathematical-statistical analysis. Results. It was found that there was a close correlation between the intensity of transpiration of tomato plants by solar radiation, relative humidity, and air temperature, the correlation coefficients are $0.99,0.96$, and 0.94 , respectively. The intensity of transpiration increases linearly with increasing solar radiation and air temperature and decreases with increasing relative humidity. The maximum values of transpiration intensity were at 12 and $14 \mathrm{~h}$, and reached 538.1 and $574.1 \mathrm{~g} / \mathrm{m} 2 \cdot \mathrm{h}$, respectively, and between 12 and $14 \mathrm{~h}$ there was a noon depression of transpiration. Based on multiple linear regression, they obtained a model of transpiration intensity of tomato plants during the day with a coefficient of determination R2 $=0.91$, standard error STr=27.5. A comprehensive statistical analysis of the obtained model was performed, which confirmed that the obtained model was statistically significant with a reliability of $95 \%$ and confirmed the hypothesis of the influence of climatic factors on the intensity of transpiration of tomato plants. The average absolute percentage error (AAPE) was $7.4 \%$. Conclusions. Based on the conducted researches the daily periodicity of transpiration intensity of tomato plants and linear dependence of transpiration intensity on the action of solar radiation, temperature, and relative humidity of air is confirmed. The influence of ecological factors on the intensity of transpiration is established based on a multiple linear regression model. The greatest influence on the intensity of tomato transpiration has solar radiation, and the smallest - air temperature, standardized regression coefficients are equal to 1.169 and 0.028 , respectively. The conducted comprehensive statistical analysis confirmed the high accuracy of the obtained model: the AAPE error is less than $10 \%$.

Key words: solar radiation, air temperature, relative humidity, multiple linear regression, statistical analysis, average absolute percentage error.

DOI: https://doi.org/10.31073/agrovisnyk202103-08

External environmental conditions are not lky regulate the degree is opened so I stomata, but also directly affect the process of transpiration. Monitoring the intensity of transpiration is of great importance in calculating the need of plants for water, in particular during irrigation. Knowing the value of leaf surface can calculate the necessary amount of water as in the need to compensate. The intensity with which transpiration occurs refers to the amount of water lost by plants over a period. Plants regulate the rate of transpiration by opening and closing the stomata [1,2]. There are a number of external factors that affect the intensity of transpiration, namely temperature, intensity of solar radiation, humidity and speed wi district in $[3,4]$. Temperature affects the transpiration rate in two ways. First, at higher temperatures, water molecules move faster, and therefore the rate of evaporation from the stomata is much higher, and secondly, the moisture content of warm air is greater than that of cold air [1, 3, 4]. At high intensity of solar radiation, the rate of photosynthesis increases. As photosynthesis increases, the amount of accumulated glucose in the protective cells increases, which reduces the water potential of the leaf. When the water potential decreases, more water enters the protective cells, making them stronger, turgor pressure of the protective cells leads to the opening of the stomata, which leads to transpiration [1, 3, 4]. At high humidity, the gradient of water potential between the inner part of the stomata of the leaf and the atmosphere is small, and the transpiration rate will be low. If the air is dry, there will be a steep gradient of water concentration between the humidity inside the stomata and the outside air, and therefore the transpiration rate will be high. When water is lost from the leaf, it forms a thin layer outside the leaf. This reduces the water potential between the leaf and the atmosphere outside. When there is wind, this layer is blown away, thus maintaining the gradient of water potential through the sheet $[1,3,4]$.

Much attention of scientists is paid to the construction of models of transpiration of greenhouse crops. The models are based on the relationship between solar radiation, water vapor pressure deficit, relative humidity and air temperature and other factors [4-11]. Environmental factors and plant growth are important factors that affect the intensity transpiration her crops, but because of the complex nature of 
relationships is difficult to use these factors to assess the intensity of transpiration. Therefore, in order to establish the influence of meteorological factors on the intensity of transpiration of plants used method of multiple linear regression (MLR) and artificial $n$ eyronnyh networks (ANNs) $[6,7,10,12,13]$. Scientists [6, 7] found that solar radiation and water vapor pressure deficiency correlate most with plant transpiration Research [6,9] found that greenhouse tomatoes high humidity air and low light levels inhibit transpiration leads to yield losses. The intensity of transpiration increases linearly with increasing solar radiation, the deficit of water vapor pressure, air velocity $[6,7,9,11,14]$ air temperature and carbon dioxide concentration do not significantly affect [9]. An increase in solar radiation by $1 \mathrm{MJ} \mathrm{m}^{-2}$.day ${ }^{-1}$ leads to an increase in transpiration of young tomato plants by $0.09 \mathrm{~mm} \cdot \mathrm{day}^{-1}$, and an increase in the deficit of water vapor pressure by $0.1 \mathrm{kPa}$ - increases transpiration by $0.013 \mathrm{~mm} \cdot \mathrm{day}^{-1}[6,9]$.

I showed an analytical review, the issue of the influence of environmental factors on the intensity of transpiration of plants in the field was given little attention, and research in the steppes of Ukraine was not. The difference and novelty of our studies is determining the intensity of transpiration of tomato plants under field production conditions.

The aim of the study is to study the influence of environmental factors on the transpiration intensity of tomato plants and to build a model of transpiration intensity based on multiple linear regression.

Materials and methods of research. The research was carried out according to the method of vegetation research Kirshin N.K. [15] during 2016-2020 biennium. On land State Enterprise Experimental farm "Brylivske" "(v. Privetnoye Oleshkivski district, Kherson region. The Dry Steppe) Institute of Water Problems and Land NAAS. To eliminate physical evaporation from the soil surface, the vegetation vessels were sealed with a film. The influence of ecological factors on the intensity of transpiration of tomato plants was studied. An early-ripening hybrid of tomato $\mathrm{H} 1015 \mathrm{~F} 1$ was used for the experiment, at the time of observations the age of the plants was 26 days from planting seedlings, and the leaf surface area of 1 plant was $0.165 \mathrm{~m}^{2}$. Transpiration measured by weight $[4,6,11,12,14]$, weighing scales used laboratory " Technovesy" TVE-60-1, accuracy class II (ISO EN 45501). From 5 to 20 hours weighing of vegetative vessels with the plant was performed every 20 minutes, at night weighed once an hour. The leaf surface area was determined by the method of A.O. Nichiporovich [16]. Observations of meteorological parameters were performed directly on the experimental site using the meteorological station iMetos, which is equipped with sensors: temperature and relative humidity, solar radiation, wind speed, precipitation. The meteorological registration interval was 20 minutes.

The intensity of transpiration was defined as the ratio of the amount of water that the plant evaporated in 1 hour to the leaf surface area of $1 \mathrm{~m}^{2}$ [17].

Research results and their discussion. According to the results of observations, it was found that the intensity of tomato transpiration is different during the day. Thus, from 0 hours to 7 hours and from 20 hours to 24 hours and the intensity of transpiration did not exceed $40 \mathrm{~g} / \mathrm{m}^{2}$.hour and averaged 30 $\mathrm{g} / \mathrm{m}^{2}$.hour during this period. From 7 o'clock to 20 o'clock the intensity of transpiration increases, in comparison with night hours, and was in the range of $126-574 \mathrm{~g} / \mathrm{m}^{2} \cdot$ hour, and its average value increased 12 times. The maximum values of transpiration intensity reached at 12 and 14 hours, and were 538.1 and $574.1 \mathrm{~g} / \mathrm{m}^{2}$.hour, respectively. Between 12 and 14 hours, the intensity of transpiration decreased, and at $12: 40$ and $13: 20$, respectively, was 427.8 and $450.0 \mathrm{~g} / \mathrm{m}^{2}$.hour (Fig. 1). These observations confirm that at noon the closure of the stomata occurs as a result of the hydroactive regulatory mechanism [2].

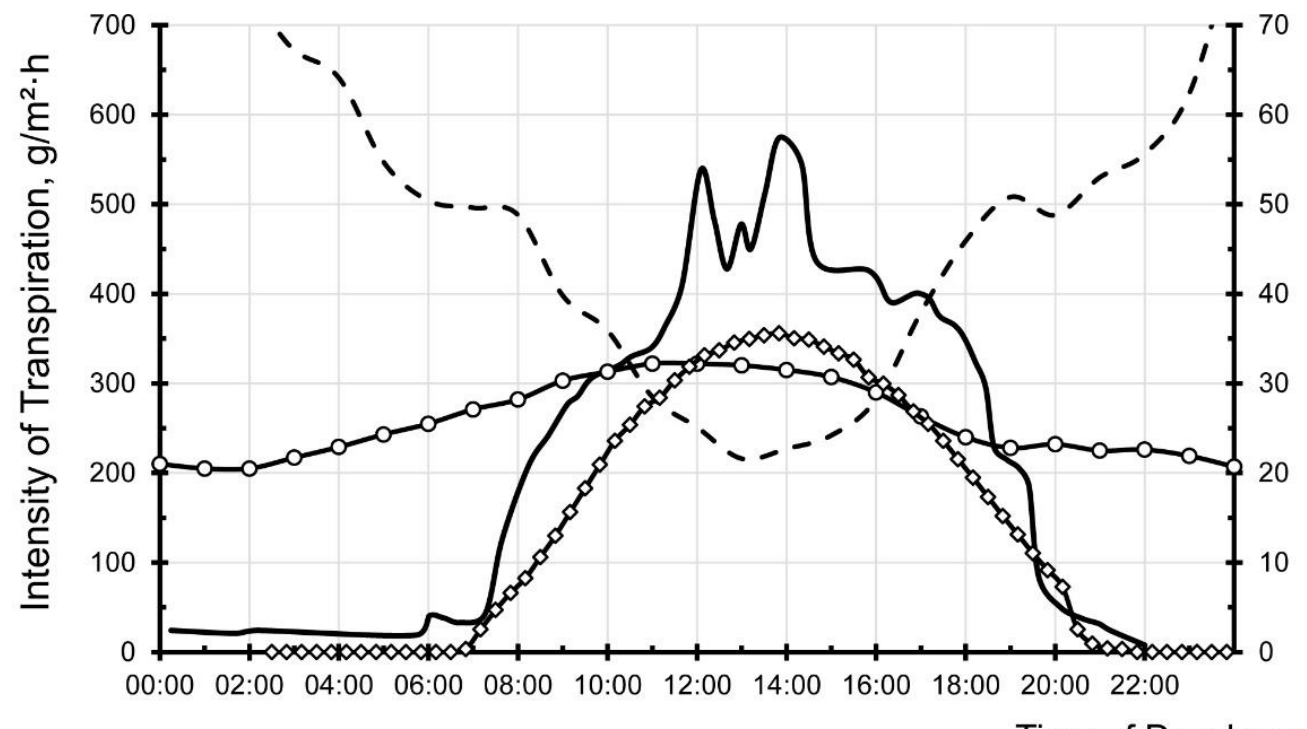

Time of Day, hour

Fig.1. Dynamics of transpiration intensity, air temperature, relative humidity and solar radiation during the day: —transpiration intensity, $\mathrm{g} / \mathrm{m}^{2} \cdot \mathrm{h} ; \multimap$ solar radiation, $\mathrm{MJ} / \mathrm{m}^{2} \cdot \mathrm{h}$;

- - relative humidity, \%; - - air temperature, ${ }^{\circ} \mathrm{C}$ 
There is a close relationship between the intensity of transpiration of tomato plants by solar radiation, relative humidity and air temperature, as indicated by pairwise correlation coefficients, which are equal to $0.99,0.96$ and 0.94 . The relationship between the intensity of transpiration tomato with climatic parameters studied is approximated by a linear function (Fig. 2-4).

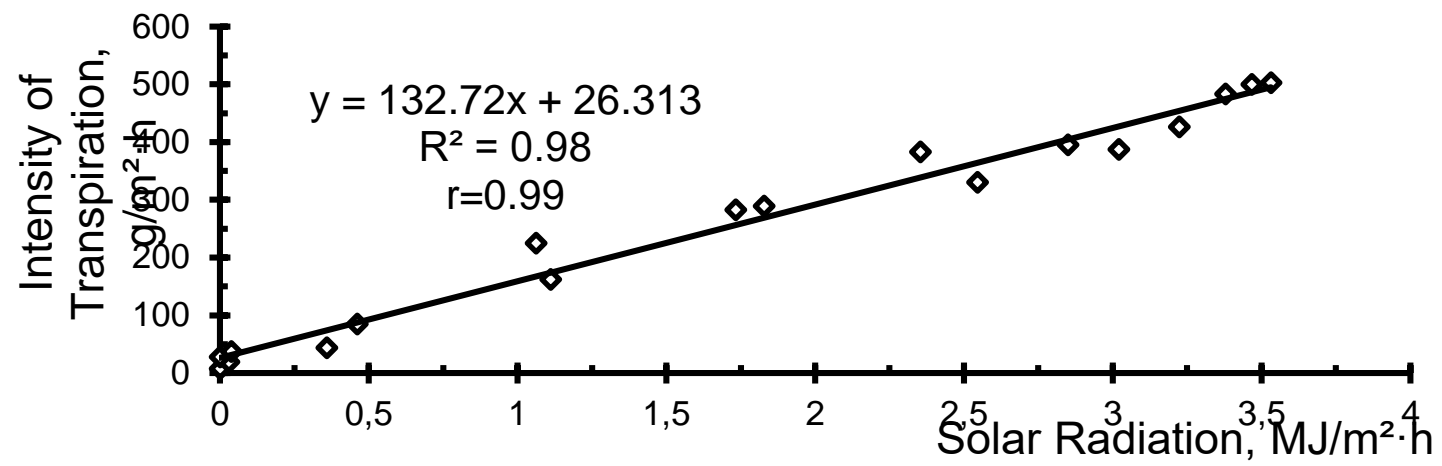

Fig. 2. Dependence of tomato transpiration intensity on solar radiation

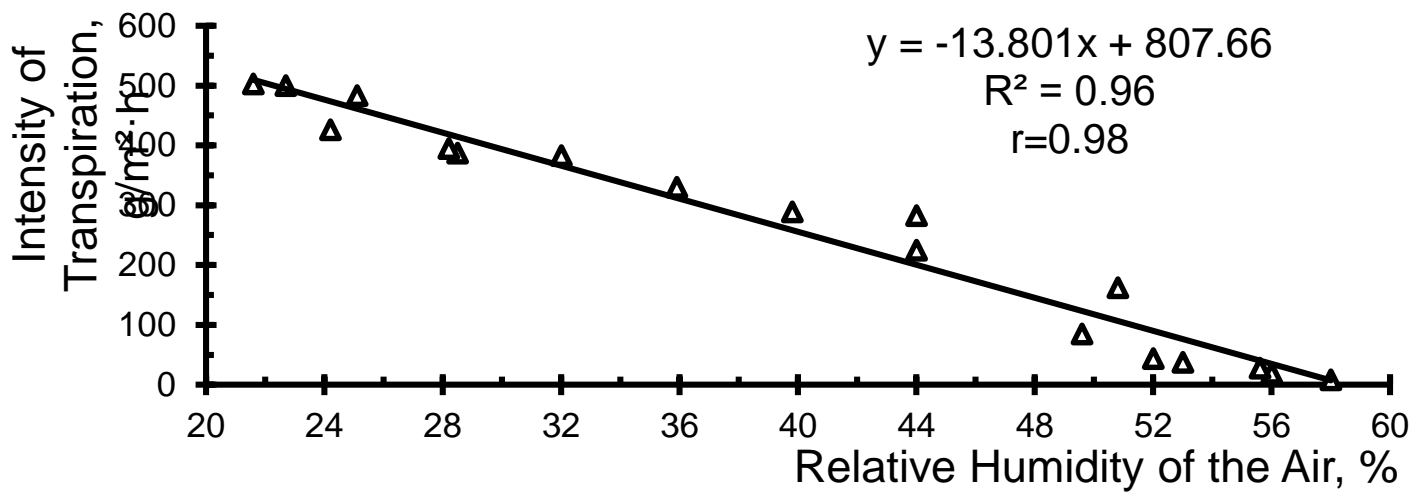

Fig. 3. The intensity of transpiration of tomato on the relative humidity of the air



Fig. 4. Dependence of tomato transpiration intensity on air temperature

To establish the combined effect of air temperature, relative humidity and solar radiation on the intensity of tomato transpiration, we used correlation-regression analysis based on the multiple linear regression equation $[6,7,10,12,13,18]$. Thanks to this method, it is possible not only to create a predictive and simulation model, but also to assess the impact of each factor that is included in the model.

According to the results of correlation and regression analysis of the data obtained a model of the dependence of the intensity of transpiration of tomato plants during the day from environmental factors:

$$
\text { Trate=1.364 } \cdot \text { Tair+3.136 } \cdot \mathrm{Rh}+156.762 \cdot \mathrm{Rs}-178.186 \mathrm{~g} / \mathrm{m}^{2} \cdot \mathrm{hour}
$$

$$
R^{2}=0.91, S_{T r}=27.5
$$

where, Trate - transpiration intensity, $\mathrm{g} / \mathrm{m}^{2} \cdot \mathrm{h}$; Tair - air temperature, ${ }^{\circ} \mathrm{C} ; \mathrm{Rh}$ - relative humidity, $\%$; Rs solar radiation, $\mathrm{MJ} / \mathrm{m}^{2} \cdot \mathrm{h} ; \mathrm{R}^{2}$ - coefficient of determination ; $\mathrm{S}_{\mathrm{Tr}}$ - standard error 
Testing the adequacy of the regression equation (Table 1) based on Fisher's test [18] confirms that the obtained equation is statistically significant with $95 \%$ confidence and confirms the hypothesis of the influence of air temperature, relative humidity and solar radiation on the intensity of transpiration of tomato plants. The inequality $F_{\text {fact }}>F_{\text {theor }}(242.3>3.2)$.

\section{Analysis of variance of the equation}

\begin{tabular}{|c|c|c|c|c|c|}
\hline \multirow{2}{*}{ Indicator } & \multirow{2}{*}{$\begin{array}{c}\text { Degree of } \\
\text { freedom, } d f\end{array}$} & Sum of squares, SS & Middle square, MS & \multicolumn{2}{|c|}{ Fisher's criterion } \\
\cline { 4 - 6 } & 3 & 551812.4 & 183937.5 & $F_{\text {fact }}$ & $F_{\text {theor }}$ \\
\hline Regression & 14 & 10625.6 & 759.0 & & 3.2 \\
\hline Remainder & 17 & 562438.0 & & & \\
\hline Total & & & & \\
\hline
\end{tabular}

Checking the adequacy of regression coefficients (Table 2) based on Student's $t$ test (t-criterion) and the level of reliability ( $p$-value) [18] indicates that all the obtained coefficients of the equation are statistically significant with a reliability of $95 \%$. The calculated $t$-criterion for all coefficients of the equation is greater than the tabular value $\left(t_{0.05}=2.110\right.$ at $\left.n=17\right)$. The level of reliability of the calculated coefficients is less than 0.05 .

\section{Regression statistics}

\begin{tabular}{|l|l|l|c|c|}
\hline Independent variable & \multicolumn{1}{|c|}{ Coefficients } & Standard error & t-test & $p$-values $(\alpha)$ \\
\hline Y- intersection & $-178,186$ & 187.210 & -2.159 & 0.035 \\
\hline Tair & 1.364 & 3.743 & 2.198 & 0.008 \\
\hline Rh & 3.136 & 2.418 & 2.357 & 0.002 \\
\hline Rs & 156.762 & 19.940 & 6.535 & 0.0004 \\
\hline
\end{tabular}

To identify the factor that most affects the intensity of transpiration of tomatoes used the method of comparing standardized regression coefficients [18] (Table 3). According to this method, the regression coefficients areconverted into conventional units. The more standardized coefficient egression the greater its impact factor studied. In our case, most second impact on the intensity of transpiration of tomato carries solar radiation, air temperature and the lowest standardized coefficient and regression, respectively equaled tion 1.169 and 0.028 .

\section{Standardized regression coefficients}

\begin{tabular}{|l|c|c|c|c|}
\hline \multicolumn{1}{|c|}{ Statistical characteristics } & $\begin{array}{c}\text { Trate }, \\
\mathrm{g} / \mathrm{m}^{2} \cdot \mathrm{h}\end{array}$ & Tair, ${ }^{\circ} \mathrm{C}$ & $\mathrm{Rh}, \%$ & $\begin{array}{c}\mathrm{Rs}, \\
\mathrm{MJ} / \mathrm{m}^{2} \cdot \mathrm{day}\end{array}$ \\
\hline Standard deviation & 181.9 & 3.7 & 12.2 & 1.3 \\
\hline Regression coefficients & & 1.364 & 3.136 & 156.762 \\
\hline $\begin{array}{l}\text { Standardized regression } \\
\text { coefficients }\end{array}$ & & 0.028 & 0.211 & 1.169 \\
\hline
\end{tabular}

For mo zualnoho ve display of results of calculation formula to figure unku 5 shows experimental and theoretical intensity of transpiration of tomato. The arithmetic mean, standard deviation of experimental data and calculated according to model 1, respectively, are 254.8;181.9 and 255.1; 181.4. To establish the accuracy of the obtained model, the average absolute percentage error (MAPE) [19] was calculated, which is $7.4 \%$, and the accuracy of the model forecast, which is $92.6 \%$, was calculated. The MARE error of the obtained model is less than $10 \%$, which corresponds to the high accuracy of the obtained dependence. 




Fig.5. Experimental and calculated intensity of tomato transpiration: — experimental, - calculated

Figure 6 shows the relationship between experimental and theoretical transpiration intensity using a linear equation.

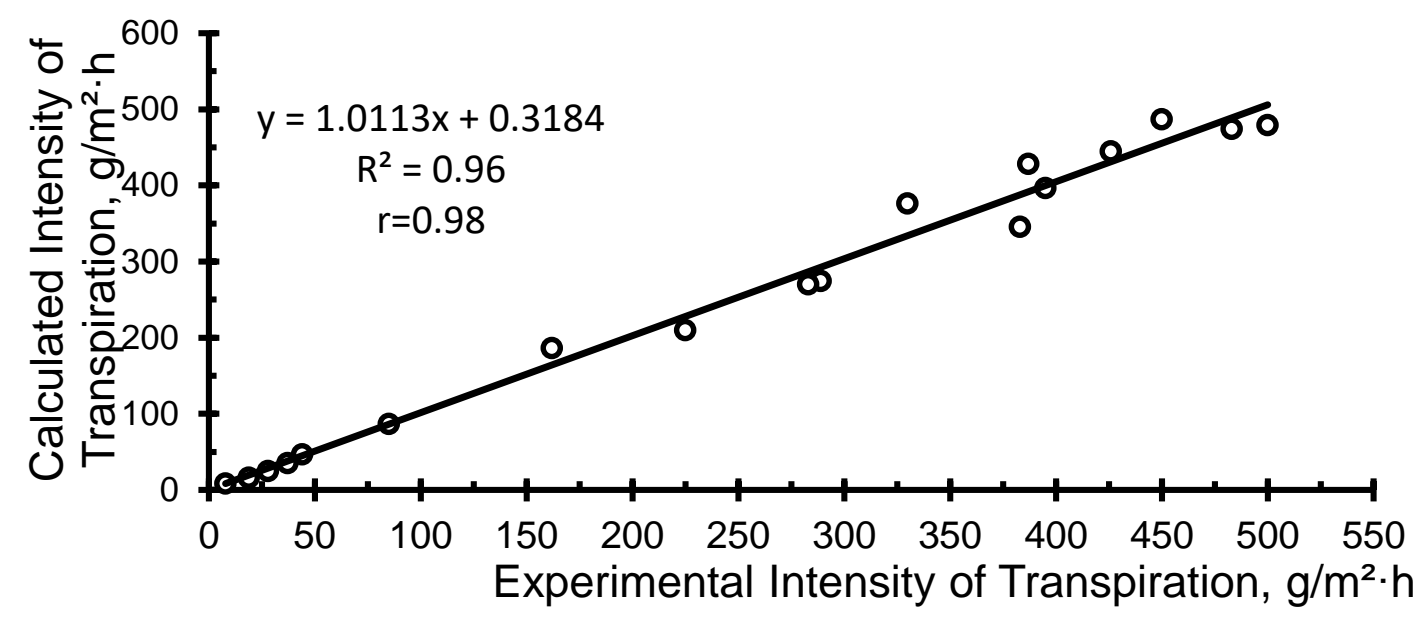

Fig.6. Relationship between experimental and calculated transpiration intensity using a linear equation

\section{Conclusions}

On the basis of the conducted researches the daily periodicity of transpiration intensity of tomato plants and linear dependence of transpiration intensity on the action of solar radiation, temperature and relative humidity are confirmed. The influence of ecological factors on the intensity of transpiration is established on the basis of multiple linear regression model. The greatest influence on the intensity of transpiration of tomato carries solar radiation, air temperature and the lowest standardized coefficient and regression, respectively equaled tion 1.169 and 0.028 . The conducted comprehensive statistical analysis confirmed the high accuracy of the obtained model, the error of MARE is less than $10 \%$.

\section{References}

1. Maksimov, N.A. (1958). Kratkiy kurs fiziologii rasteniy [A short course in plant physiology]. 9th, rev. and enl. Moscow; L. Selkhozgiz. [In Russian].

2. Makrushyn, M.M., Makrushyna, Ye.M., Peterson, N.V., \& Melnykov, M.M. (M.M. Makrushyn (Ed.)). (2006). Fiziolohiya roslyn [Plant physiology]. Vinnytsia. Nova Kniga. [In Ukrainian].

3. Seryakova, L.P. (1971). Meteorologicheskiye usloviya $i$ rasteniya [Meteorological conditions and plants]. L. [In Russian].

4. Wallach, R., Da-Costa, N., Raviv, M., \& Moshelion, M. (2010). Development of synchronized, autonomous, and self-regulated oscillations in transpiration rate of a whole tomato plant under water stress. J. of Experimental Botany, 61 (12), 3439-3449. doi: 10.1093/jxb/erq168

5. Boulard, T., \& Jemaa, R. (1993) Grennhouse tomato crop transpiration model application to irrigation control. Acta Hortic, 335, 381-388.

6. doi: 10.17660/ActaHortic. 1993.335.46 
7. Halil, Kirnak, Ted, H. Short, \& Hansen, R.C. (2002). Studies on the relationships among moisture tension, microclimate and transpiration rate of container grown Acer rubrum. J. Appl. Hort, 4(2), 6569. Available at: http://horticultureresearch.net/pdf/Acerrubram.pdf

8. Halil, Kirnak, \& Ted, H. Short (2001). Dynamic Transpiration of a Greenhouse Grown Potted New Guinea Impatiens. Tarim Bilimleri Dergisi, 3, 13-20. doi:10.1501/Tarimbil_0000000641

9. Jolliet, O. (1994). Hortitrans, a Model for Predicting and Optimizing Humidity and Transpiration in Greenhouses. Journal of Agricultural Engineering Research, 57(1), 23-37. doi:10.1006/jaer.1994.1003

10. Jolliet, O., \& Bailey B.J. (1992). The effect of climate on tomato transpiration in greenhouses: measurements and models comparison. Agr. Forest Meteorol, 58, 43-62. doi:10.1016/01681923(92)90110-P

11. Katsoulas, N., \& Stanghellini, C. (2019). Modelling Crop Transpiration in Greenhouses: Different Models for Different Applications. Agronomy, 9(7), 392. doi:10.3390/agronomy9070392

12. Young, Bae Choi, \& Jong, Hwa Shin (2020). Development of a transpiration model for precise irrigation control in tomato cultivation. Scienta Horticulturae, 267, 109358. doi:10.1016/j.scienta.2020.109358

13. Du, Sung Nam, Taewon, Moon, Joon, Woo Lee, \& Jung, Eek Son (2019). Estimating transpiration rates of hydroponically-grown paprika via an artificial neural network using aerial and root - zone environments and growth factors in greenhouses. Hortic. Environ. Biotechnol, 60, 913-923. doi:10.1007/s13580-019-00183-z

14. Shirgure, P.S. (2012). Evaporation modeling with multiple linear regression techniques - a review. Scientific Journal of Review, 1(6), 170-182. Available at: https://www.researchgate.net/publication/295502806

15. Leperen, W. Van, \& Madery H. (1994). A new method to measure plant water uptake and transpiration simultaneously. Journal of Experimental Botany, 45 (1), 51-60. doi:10.1093/jxb/45.1.51

16. Kirshin, N.K. (1989). Metodika eksperementa: Vegetatsionnyy metod [Experimental technique: Vegetation method]. Sverdlovsk: UrGU. [In Russian].

17. Nichiporovich, A.A., Kuzmin Z.Ye., Polozova, L.Ya. (1969). Metodicheskiye ukazaniya po uchetu i kontrolyu vazhneyshikh pokazateley protsessov fotosinteticheskoy deyatelnosti rasteniy [Methodical instructions for the accounting and control of the most important indicators of the processes of photosynthetic activity of plants]. Moscow [In Russian].

18. Tretyakova, N.N. (Ed.). (1990). Praktikum po fiziologii rasteniy [Workshop on Plant Physiology] 3rd. Moscow: Agropromizdat. [In Russia].

19. Baraz, V.R. (2005). Korrelyatsionno-regressionnyy analiz svyazi pokazateley kommercheskoy deyatelnosti s ispolzovaniyem programmy Excel [Correlation-regression analysis of the relationship of indicators of commercial activity using the Excel program]. Yekaterinburg: GOU VPO "UGTU-UPI". [In Russian].

20. Shcherbakov, M.V., Brebels, A., Shcherbakova, N.L. at al. (2013). A Survey of Forecast Error Measures. World Applied Sciences Journal, 24, 171-176. doi: 10.5829/idosi.wasj.2013.24.itmies.80032 